\title{
The Modernization of Traditional Chinese Culture in the Perspective of Marxism in China
}

\author{
Jing Wang \\ Jiangsu College of Finance \& Accounting \\ Lianyungang, China \\ Nanjing University of Science \& Technology \\ Nanjing, China
}

\begin{abstract}
This article begins with the demonstration of the relationship between Marxism in China and the transformation of the modernity of Chinese traditional culture, discussed the practical significance and necessity of the transformation of the modernity of Chinese traditional culture. It explores the significance and path of the transformation of the modernity of Chinese traditional culture from three aspects: the guidance of Chinese Marxist thought, the guidance of social core values, and the innovative thinking that keeps pace with the times.
\end{abstract}

Keywords-Marxism; sinification; traditional culture; modernity

\section{INTRODUCTION}

The report of the 19th CPC National Congress pointed out: "The development of a culture of socialism with Chinese characteristics is based on the guidance of Marxism, adherence to the Chinese cultural stance, and on the basis of contemporary China's reality, combined with the conditions of the present era, and development oriented toward modernization, the world, and the future. The scientific and popular socialist culture promotes the coordinated development of socialist spiritual civilization and material civilization." Under the background of the era of cultural globalization, with the guidance of the Chinese Marx doctrine, how to inherit and carry forward the essence of Chinese excellent traditional culture and explore the significance and path of the transformation of the modernity of Chinese traditional culture with the times, is a major issue for the Chinese dream of enhancing cultural self-confidence and cultural power.

\section{THE DIALECTICAL AND INTERACTIVE RELATIONSHIP} BETWEEN THE LOCALIZATION OF MARXISM IN CHINA AND THE MODERniZATION OF CHINESE TRADITIONAL CUlturE

Marxist "sinicization" cannot be equivalent to the "general principle" of Marxism plus the "individual" instance of Chinese history and reality, nor can it be equated with the "unity" of "universal law" and "special Chinese national conditions." Marxism in China is a major theoretical and practical achievement. The important value and significance of its existence and embodiment is to continuously answer, solve and complete the one-by-one questions and tasks put forward by the times.

The sinicization of Marx is often a topic of the times, and the relationship between Marxism in China and traditional Chinese culture is full of controversy. Scholars generally believe that the debate on this issue focuses on the historical and logical relations between Marxism and traditional culture: "Critique - Transcendence" and "Inheritance Innovation." Although there are many disputes over the relationship between Marxism and traditional culture, they are not in conflict with each other. They are mutually reinforcing and mutually reinforcing. This integration has confirmed the dialectical interaction between Marxism in China and the modernization of Chinese traditional culture: In other words, Marxism promotes the modern transformation of traditional Chinese culture in China. At the same time, the modernization of traditional Chinese culture has promoted the sinicization of Marxism. ${ }^{[1]}$

\section{A. Marxism in China Promotes Modernization of Chinese Traditional Culture}

Marxism and the Relationship between Confucianism and Chinese Traditional Culture. It essentially represented the collision and communication at the highest level of contemporary Chinese and Western cultures. The result of the fusion is the transformation of the Chinese-style Marxism and the modernity of Chinese traditional culture. In the strong collision and exchange, Marxism has become and will eventually become the dominant cultural form and guiding ideology of Chinese society. The transformation of the modernity of Chinese traditional culture can only be based on the reality of China under the guidance of Marx's doctrine, facing the future, and criticizing all the excellent cultural heritages and historical traditions of ancient and modern, conforming to the development logic of "critical transcendence" and "inheritance - innovation", and pushing forward the new form of new national culture, in order to complete the transformation of modernity. This is the historical requirement for China's modernization drive and the promotion of national culture. It is also an inevitable trend for the internal integration of Marxism in China and traditional Chinese culture. 


\section{B. The Modernization of Chinese Traditional Culture Promote the Localization of Marxism in China}

Marxism can only be accepted by Chinese advanced intellectuals and the vast number of workers and peasants in thinking and emotion only if it is integrated into China's history and traditional culture. The powerful force of Marxism in China is whether it can be completely combined with the reality of China, especially the combination of China's outstanding traditional culture. Because of the abstractness and complexity of Marxism itself, it is relatively easy to be affected by traditional Chinese culture. For example, some dregs in traditional culture that do not conform to the laws of scientific development are very easy to deviate and deny Chinese Marxism. In its original nature, it lost its guidance on the scientific theory of China's socialist modernization. With the development of the times, China's traditional culture has constantly adapted itself to the new situation and continuously achieved the transformation of modernity. This is a process that has squandered and broke new ground. It is this dross transformation of modernity that has removed the impediments to the development of Marxism in China's traditional culture. Therefore, only by inheriting China's outstanding traditional culture can Marxism win in China. That is to say, the modernization of Chinese traditional culture will promote the development of Marxism in China

\section{ThE PRACTICAL SigNIFICANCE AND NECESSITY OF THE TRANSFORMATION OF THE MODERNITY OF CHINESE TRADITIONAL CULTURE}

China is an ancient civilization with a history of 5,000 years and has a long tradition of cultural traditions. Traditional culture is the historical treasure of the Chinese nation and it implies a continuous national spirit. Chinese traditional culture contains the deepest spiritual pursuit of the Chinese nation, including the most fundamental spiritual genes of the Chinese nation and represents the unique spiritual identity of the Chinese nation. The transformation of the modernity of Chinese traditional culture has its contemporary significance and necessity.

\section{A. Chinese Traditional Culture is the Driving Force Behind the Chinese National Spirit}

China is an ancient civilization with a history of 5,000 years and has a long tradition of cultural traditions. Traditional culture is the historical treasure of the Chinese nation and it implies a continuous national spirit. Since the reform and opening up, with the transformation of traditional society into modern society, the material level of people's lives has grown rapidly, but our spiritual civilization construction has lagged behind. Once it is separated from the basic spirit of the fine traditional Chinese culture, the modern transformation of the excellent Chinese traditional culture will be water without trees or water.

First, Chinese traditional culture implies the spirit of "people harmony." The "people harmony" here refers to "humanities" and "harmony" .The "humanistic" spirit is the challenge of the industrious and courageous Chinese people to "the fate of heaven" and "theocracy". "Man will conquer nature" determines the path of Chinese culture, and separates Chinese culture from religious control dominated by salvation and belief. The "Harmony" spirit refers to the harmonious coexistence between people, and it also includes the coordination and smoothness of things. Such as Confucius's "Use of ceremonies and harmony are expensive." Mencius's "Better than heaven and earth, and the geography is not as good as people" are all examples of the spirit of "people and harmony." [2] In the process of transforming the modernity of Chinese traditional culture, seeking harmony and focusing on the overall cultural color is proved by practice.

Second, there is a "natural" spirit in Chinese traditional culture. In traditional Chinese culture, Taoism is known for advocating nature. From the perspective of Taoism, "the way of man and the law, the way of heaven, the way of heaven, and the nature of Taoism", Taoists believe that nature is the ultimate of Tao. People must learn to respect nature and love nature, and they must consciously follow the laws of nature. This is the historical development law of the transformation of the modernity of Chinese traditional culture in line with the scientific concept of development.

Third, the "transformation" spirit is contained in Chinese traditional culture. In the "Yi" which has been praised as "the first of the five classics", there is a core idea that "the poor will change, the change will pass, and the rule will be long". This idea is also consistent with the requirements of Marxist scientific development concept. The transformation of modernity in Chinese traditional culture is to preserve the essence of excellent traditional culture and gradually move toward new glory in the process of thinking and changing.

\section{B. The Necessity of Modernization of Chinese Traditional Culture}

General Secretary Xi Jin-ping pointed out: "For a nation and a country, the most lasting and deepest force is the core value that is recognized by the whole society. The fundamental task of cultivating and carrying forward the socialist core values as a unity of soul-stirring and strengthening the foundation is a fundamental task." Chinese traditional culture contains the deepest spiritual pursuit of the Chinese nation, including the most fundamental spiritual genes of the Chinese nation and represents the unique spiritual identity of the Chinese nation. We must be good at organically uniting Chinese traditional culture and modernity, closely integrated, developing in inheritance, and inheriting in development.

With the development of politics and economic globalization and rapid progress in science and technology, cultural exchanges between countries have also become more frequent. Communication in the field of ideological and cultural ideology is also forming a situation of confrontation among countries in the world. For example, Western countries have used online game culture to instill Western values in Chinese teenagers. They have even been engendered with violence and pornography, which has greatly jeopardized the stable development of our country's 
society. At the same time, it has also used the invasion of Western festivals' cultural economy in an attempt to make our country's teenagers indifference and traditions. Although the situation in which the vicious Western countries attempted to infiltrate China's culture has not achieved remarkable results, we must not relax our vigilance and must build a discourse system with Chinese characteristics. Cultural security is the most important guarantee for a country. Just as Xi Jin-ping said that "Excellent traditional culture is the foundation for the inheritance and development of a nation and a nation. If it is lost, it cuts off the spiritual lifeline." In the new era, the transformation of the modernity of China's excellent traditional culture is not only a valuable asset for our current socialist cultural construction, but also an effective factor for enhancing the country's cultural soft power and maintaining the security of national culture. In sum, historical experience has proved that modernization is the only way to achieve the great rejuvenation of the Chinese nation. The renaissance of the nation is also a renaissance of traditional culture. In the face of new historical opportunities and opportunities, China's fine traditional culture must undergo modern transformation in order to adapt to social trends and realize the Chinese dream as soon as possible.

\section{KeEP PACE WITH THE TIMES AND CREATE A BASIC PATH FOR THE MODERNITY CONSTRUCTION OF CHINESE} TRADitional CUlTuRE

How to inherit and carry forward the essence of Chinese excellent traditional culture and advance with the times to explore the path of modernization of Chinese traditional culture in the context of the era of cultural globalization, with Chinese Marxism as the guide, is to promote cultural self-confidence and cultural power China's dream is a major research topic.

\section{A. Using the Developing Marxism to Guide the Transformation of the Modernity of Chinese Traditional Culture}

As a scientific theory, Marxism is abstracted from the objective development of human social practice. Development is the breaking of the old and the new, development is to promote profit, and development is the dialectical nature of Marxism. Engels repeatedly emphasized before his life: "Our theory is a developing theory, not a dogma that must be thoroughly and mechanically repeated." Therefore, the assertion that "using the developing Marxism to guide practice" is a profound summary of a long and dynamic historical experience, accurately expounding the inherent requirements of Marxist theory and the development and reform of socialist practice.

Mr. Zhang Yin-nian pointed out: "The combination of Marxism and China's outstanding traditional culture should be the dominant direction of Chinese cultural development." The theoretical achievement of Marxism in China has provided a theoretical basis for the transformation of Chinese traditional culture modernity. Chinese culture is profound and profound, but it has deep foundations. ${ }^{[3]}$ However, if we want to under the intense impact of multiculturalism in the world, we must persist in cultivating the essence of traditional culture handed down from generation to generation and maintain the correct direction and pure bloodlines of traditional cultural modernity. We must adhere to the development. Marxism is a scientific concept of development to guide practice. The critical logic of modernity in the practice of Marxism lies in the fact that criticism should be guided by practical problems and the problems that hinder the development of modernization should be the key focus. The transformation of the modernity of traditional culture is a practical activity that criticizes the old ideology, grasps the discourse power of cultural construction, and then constructs a new cultural concept. The reforms should use modernity as the yardstick, and constantly summarize the experience and lessons of the cultural conflict and integration process between ancient and modern China and foreign countries in the course of development and embark on a healthy modernization road.

\section{B. Guiding the Transformation of Modernity of Traditional Culture with Socialist Core Values}

The core values of socialism are rich in content and profound. The core values of socialism are the essence of the socialist ideology and the spiritual banner that leads the transformation of the modernity of traditional Chinese culture. Without the guidance and leadership of socialist core values, traditional Chinese culture will lose its way in the process of modernity transformation. Judging from the current situation, as the multi-polarization of the world and the deepening of economic globalization, countries in the economy, military, science and technology, such as the overall national strength competition, the ideological field among nations is also turbulent. Since the reform and opening up, the influx of Western culture has greatly affected the development of China's traditional culture. For example, the popularity of the Western Festival culture in recent years has greatly reduced the traditional atmosphere of traditional Chinese festival culture. Therefore, we must base ourselves on the reality of China and grasp the trend of the times. We must adhere to the core values of socialism guided by Marxism and unswervingly follow the path of cultural development with socialism with Chinese characteristics.

The 18th National Congress of the CPC set out from the practice of socialism with Chinese characteristics, inherited and carried forward the traditional culture of the Chinese nation, and drew on the fruits of human civilization's innovation, and put forward the "three advocacy": "advocate prosperity, democracy, civilized harmony, advocate freedom, equality, Justice, the rule of law, advocacy for patriotism, dedication, integrity, and friendliness." The core value of socialism is the soul of ideological rejuvenation, and it is the foundation of a strong cultural country. Its value system fully embodies the common ideal of socialism with Chinese characteristics, adheres to the national spirit and the spirit of the times, and advocates the establishment of a correct world outlook, outlook on life, and values. Comrade Xi Jin-ping once said during the group study of the Politburo of the CPC Central Committee: "Core values are the soul of cultural soft power and the focus of cultural soft power construction. This is the deepest factor that determines the nature and direction 
of culture." ${ }^{[4]}$ Therefore, only by insisting on the society core values of the Guiding Principles are the guiding ideology. Sticking to the use of the Marxist world outlook and methodology, the modernization of China's outstanding traditional culture will not deviate from the track of social development and it will be better able to set sail for the socialist modernization drive.

\section{With the Creative Thinking of Keeping Pace with the Times, Creating the Modern Transformation of Traditional Culture}

The term "Advancing with the Times" is derived from "The Way of All the Benefits and the Time of the Past" in the book of "Zhou Yi". It means changing the time, taking the opportunity, and making judgments suitable for the needs of the times. "Book of Changes" is the theoretical source and wisdom of natural philosophy and humanistic practice in Chinese traditional culture, and is known as "the source of the road." "Advancing with the times" is a reflection of the philosophical wisdom of the realization of the development of the modernization of traditional culture. The main point is "in time." "Time and time" emphasizes that people's thoughts, words and deeds can only adapt to natural laws and development procedures before they can innovate and make progress in the process of change.

"Advancing with the times" is a great call with distinctive characteristics of the times. In today's China, "advancing with the times" is a high-frequency keyword. It is consistent with "reform and opening up," "modernity transformation," "Chinese characteristics," "scientific development," "traditional culture," and "ideology." Words such as these are closely linked and have become landmarks in the new era. The report of the 19th National Congress put forward a new historical orientation for China's development. Socialism with Chinese characteristics has entered a new era. This major judgment and the "new era, new mission, and new journey" carry forward the past and leave the future! Advancing with the times is a major trend in history, and continuous innovation is the main theme of the era. In today's great era of calling for cultural innovation, Chinese traditional culture can only truly promote the transformation of its modernity, if it is to achieve the "harmony".

\section{CONCLUSION}

The report of the Nineteenth Congress proposed to promote the creative transformation and innovative development of China's outstanding traditional culture. $\mathrm{Xi}$ Jin-ping emphasized: "We are good at uniting and closely integrating the promotion of excellent traditional culture with the development of a realistic culture, developing in succession, and inheriting in development." ${ }^{[5]}$ Therefore, the transformation of the modernity of traditional culture must be guided by the Chinese Marxist scientific development concept and learn from foreign outstanding cultural achievements. Make it compatible with China's real culture, advance with the times, and form a new socialist culture with Chinese characteristics. Cultural self-confidence is the source of motivation for building a strong socialist culture. We must use advanced cultural concepts to arm our minds, help social and economic development, and contribute to the realization of the Chinese dream.

\section{ACKNOWLEDGEMENT}

Thanks to my mentor who encountered many problems during the writing of the dissertation. Under the patience of the mentor, the problems were solved. At the same time, I would like to thank my parents who not only cultivated my strong interest in Chinese traditional culture, but also helped me to have a sincere return to the soul during my long journey of life, and also helped me to successfully complete graduation. The paper provides great support and help.

\section{REFERENCES}

[1] Chen Xian-da. Marxism and Chinese Traditional Culture [M]. Beijing: People's Publishing House, 2015.

[2] Chinese Marxism and Contemporary [M]. Beijing: Higher Education Press, 2015.

[3] Zhang Yun-yi. Chinese Culture and Marxism [M]. Beijing: People's Publishing House, 2015.

[4] Zhao Shi-fa. Marxist Sinicization in the Process of Modernization [M]. Beijing: People's Publishing House, 2016.

[5] Xi Jin-ping. A speech at the opening ceremony of the 5th Anniversary of Confucius International Symposium and the 5th General Assembly of the International Confucian Association. [N]. People's Daily, 2014.9.25. 